\title{
The Effects of Some Imidazopyrazine Derivatives on Telomerase Inhibition, mtDNA Damage and mtDNA Copy Number
}

\author{
Ayşe Gül Mutli ${ }^{*}$, Abdulkerim Bilginer², Ismail Kayağil ${ }^{3}$, Hülya Yıldız², Ülkü Bayhan, \\ İnanç Yılmaz ${ }^{4}$, Şeref Demirayak ${ }^{5}$ \\ ${ }^{1}$ Mehmet Akif Ersoy University, Arts and Sciences Faculty, Department of Molecular Biology and Genetics, Burdur, Turkey \\ ${ }^{2}$ Mehmet Akif Ersoy University, Arts and Sciences Faculty, Department of Biology, Burdur, Turkey \\ ${ }^{3}$ Mehmet Akif Ersoy University, Arts and Sciences Faculty, Department of Chemistry, Burdur, Turkey \\ ${ }^{4}$ Mehmet Akif Ersoy University, Arts and Sciences Faculty, Department of Physics, Burdur, Turkey \\ ${ }^{5}$ Medipol University, Faculty of Pharmacy, İstanbul, Turkey
}

\begin{abstract}
Imidazopyrazine derivatives have been studied for their curative effects on some diseases like cancer and neurological problems; also, some of these molecules have been patented. Primary human cells exhibit limited replicative potential but the cancer cells divided unlimitedly with passage in culture. This immortality is mainly a result of telomerase activity. We investigated the possible telomerase inhibitor effect and possible mtDNA damage action of five imidazopyrazine derivatives. Telomerase activities were measured by the PCR-ELISA based TRAP method and mtDNA damage assays were achieved by quantitative PCR. We used zebrafish as a model organism for our research. In the application of 6-(4-Metylphenyl-8-(4chlorophenyl)imidazo[1,2-a]pyrazine $\left(\mathrm{C}_{19} \mathrm{H}_{14} \mathrm{~N}_{3} \mathrm{Cl}\right)$, it was determined that this compound inhibit telomerase activities to a statistically significant degree. The obtained results from molecular docking studies also supported the experimental results. Accordingly, this compound has the probability to be used as an anti-cancer agent after detailed studies.
\end{abstract}

Keywords: Imidazopyrazine derivatives, Telomerase inhibition, mtDNA damage, mtDNA copy number, anticancer drugs

\section{INTRODUCTION}

The use of chemotherapy to treat cancer began at the start of the 2oth century. In the 1960 s and early 1970s, chemotherapy could cure acute childhood leukemia Hodgkin's disease. These advances of the drug development created hope for to cure cancers. Today, targeted therapies provide a broad perspective for treatment of more diseases. ${ }^{1}$

*Corresponding Author: Ayşe Gül Mutlu agmutlu@gmail.com 
The molecules that were synthesized by researchers in the past have become important drugs today. Imidazopyrazine derivatives have been studied for their curative effect on some diseases like cancer and neurological problems; also, some of these molecules have been patented (US7189723 B2 ${ }^{2}$, WO2002010170 $\mathrm{A1}^{3}$, US7259164 B2 ${ }^{4}$, US7393848 B25).

We investigated the possible telomerase inhibitor effect of five imidazopyrazine derivatives synthesized by Demirayak and Kayagil. According to their research, these molecules have cytotoxic effects on some types of cancer cells. ${ }^{6}$ There were no data about the mechanism of cytotoxic action but these imidazopyrazine derivatives have structural similarities with some telomerase inhibitors.

Telomeres are specialized functional complexes that protect the ends of eukaryotic chromosomes. The telomeric DNA sequences are tandem repeats of a short hexameric sequence unit in most species. ${ }^{7}$ Greider and Blackburn identified a specialized DNA polymerase in extracts from the Tetrahymena, that extends the chromosome ends in eukaryotes. ${ }^{8}$ Telomerase adds multiple copies of certain DNA unit to the terminal portion of one strand of the repeat tract. ${ }^{7}$

Telomerase is a very important enzyme for the aging process and carcinogenesis. Primary human cells exhibit limited replicative potential but the cancer lines divided indefinitely with passage in culture. ${ }^{9}$ Human cancer cells must compensate the progressive loss of telomeric DNA by cell division to grow indefinitely. ${ }^{10}$ This immortality is mainly a result of telomerase activity. Telomerase is expressed in more than $85 \%$ of cancer cells ${ }^{11}$, but in some cells, the telomere length could be maintained in the absence of telomerase. It has been revealed that one or more alternative telomerase-independent mechanisms exist in human cells. ${ }^{10}$

Telomere shortening may cause aging and death. Some evidence suggests that the progressive loss of telomeric repeats of chromosomes may function as a molecular clock that triggers senescence. ${ }^{12-14}$ Epidemiological researches show that shorter telomeres may be associated with many age related diseases. ${ }^{12}$ Studies showed that the telomerase gene therapy in mice delays aging and increases longevity. ${ }^{15,16}$

The aim of this study is the investigation of the telomerase inhibitor effects of some diarylimidazopyrazine derivatives and to search for possible mtDNA damage action.

Toxic materials may generate damage on mitochondrial DNA (mtDNA). ${ }^{17-19}$ mtDNA damage may trigger mitochondrial dysfunction. ${ }^{20}$ Entire mitochondrial genome codes for genes are expressed while nDNA contains a large amount of non-transcribed sequences. Because of that the damage to mtDNA could be po- 
tentially more important than the nDNA damage. Also mtDNA is continuously replicated even in terminally differentiated cells. Therefore, somatic mtDNA damage potentially causes more adverse effects on cellular functions. ${ }^{21}$

We used zebrafish as a model organism for our research. The zebrafish (Danio rerio) has been developed as a powerful model for aging, cancer, developmental biology and some aging-related diseases. ${ }^{22}$ One of the best model organisms for telomerase studies is the zebrafish. Conversely to the inbred laboratory mouse, zebrafish have heterogeneous telomeres of human-like length and zebrafish telomeres shorten with age. ${ }^{23}$

\section{METHODOLOGY}

\section{Maintenance of Zebrafish}

We used the spleen of zebrafish for measuring telomerase enzyme activity and liver for mtDNA damage. Zebrafish (Danio rerio) were maintained at $24 \pm 2{ }^{\circ} \mathrm{C}$ with a light/dark cycle of 14:10 hours and they were fed with dry flake food. The fish were anesthetized with ice before injections and excising of organs (10 fishes for each group). All zebrafish applications were approved by the Ethical Committe of the Mehmet Akif Ersoy University (27.01.2014/57 and 24.02.2015/114).

\section{Diarylimidazopyrazine Derivatives}

We investigated the possible telomerase inhibitor effect of five imidazopyrazine derivatives originally synthesized by Demirayak and Kayagil (2005). Diarylimidazopyrazine derivatives that used in this study were coded as 2j, 2m, 2n, 20 and 2p (Table 1 and Figure 1). Diarylimidazopyrazine derivatives were dissolved in DMSO. We decided $10^{-5} \mathrm{M}$ concentration for these molecules according to results of cytotoxic tests achieved by NCI (National Cancer Institute of USA) ${ }^{6}$. Ten fishes were analyzed from each group. Compounds and DMSO were injected as $7 \mu \mathrm{l}$ to the fishes. After 150 minutes, spleens and livers were excised.<smiles>[R]c1ccc(-c2cn3ccnc3c(-c3ccc([R])cc3)n2)cc1</smiles>

Figure 1. Imidazopyrazine derivatives 
Table 1. Diarylimidazopyrazine derivatives that used in this study.

\begin{tabular}{|l|c|c|}
\hline Compounds & $\mathbf{R}$ & $\mathbf{R}$ \\
\hline 2j / 6-(4-Methylphenyl)-8-(4-methoxyphenyl)imidazo[1,2-a]pyrazine & $\mathrm{OCH}_{3}$ & $\mathrm{CH}_{3}$ \\
\hline 2m / 6-phenyl-8-(4-chlorophenyl)imidazo[1,2-a]pyrazine & $\mathrm{Cl}$ & $\mathrm{H}$ \\
\hline 2n / 6-(4-Methylphenyl)-8-(4-chlorophenyl)imidazo[1,2-a]pyrazine & $\mathrm{Cl}$ & $\mathrm{CH}_{3}$ \\
\hline 20 / 6-(4-Methoxyphenyl)-8-(4-chlorophenyl)imidazo[1,2-a]pyrazine & $\mathrm{Cl}$ & $\mathrm{OCH}_{3}$ \\
\hline 2p / 6-(4-Chlorophenyl)-8-(4-chlorophenyl)imidazo[1,2-a]pyrazine & $\mathrm{Cl}$ & $\mathrm{Cl}$ \\
\hline
\end{tabular}

\section{Telomerase Assay}

Telomerase activities were measured by Roche TeloTAGGG Telomerase PCR ELISA kit, according to the manufacturer's instructions. This kit allows highly specific amplification of telomerase-mediated elongation products combined with nonradioctive detection following an ELISA protocol. Relative Telomerase Activity (RTA) values were calculated for $\mathrm{mg} / \mathrm{ml}$ protein. Protein values were determined by the Bradford method (Bradford Reagent SIGMA B 6916).

\section{Determination of mtDNA Damage and Copy Number}

SIGMA G1N350 Genomic DNA kits were used for total DNA isolation using the methods indicated in the technical bulletin. Invitrogen (Molecular Probes) Pico Green dsDNA quantitation dye and QUBIT 2.0 fluorometer were used for template DNA quantitation and for the fluorometric analysis of PCR products. A crucial step in the QPCR method is the adjusting the concentration of DNA sample. The accuracy of the assay relies on initial template quantity because all of the samples must have the same amount of DNA. The Pico Green dye has not only proven to be an efficient method for template quantitation but also for PCR product analysis. ${ }^{24,25} \mathrm{DMSO}$ (in a volume equivalent to $4 \%$ of total volume) was added to $5 \mathrm{ng}$ of template total DNA in each PCR tube. Thermostabil polymerase used was Thermo Phire hot start II DNA polymerase.

Primers were designed for zebrafish (Danio rerio) mtDNA small fragment (95 bp) as:

\section{5' CCCATACTAAAAGCACGCCC 3' \\ 5' CCAGCAACCCTTATTTCGGG 3'}

Primers were designed for zebrafish (Danio rerio) mtDNA large fragment (10403 bp) as:

\footnotetext{
5' ACCCATGCCCAAGAGATCAA 3'

5' TTTTCGAGTCACCGGTCTCA 3'
} 
For long fragment PCR amplification, DNA was denatured initially at $98^{\circ} \mathrm{C}$ for one minute; the material then underwent $21 \mathrm{PCR}$ cycles of $98^{\circ} \mathrm{C}$ for 10 seconds, $60^{\circ} \mathrm{C}$ for 45 seconds, and $69^{\circ} \mathrm{C}$ for five minutes. Final extension was allowed to proceed at $69^{\circ} \mathrm{C}$ for five minutes.

For small fragment PCR amplification, DNA was denatured initially at $98^{\circ} \mathrm{C}$ for one minute; the material then underwent $21 \mathrm{PCR}$ cycles of $98^{\circ} \mathrm{C}$ for 10 seconds, $58^{\circ} \mathrm{C}$ for 45 seconds, and $72^{\circ} \mathrm{C}$ for 10 seconds. Final extension was allowed to proceed at $72^{\circ} \mathrm{C}$ for two minutes.

The QPCR method was used to measure mtDNA damage. The lesion present in the DNA blocked the progression of any thermostable polymerase on the template, so a decrease in DNA amplification was observed in damaged templates. The QPCR method is highly sensitive and useful to measurements of DNA damage and repair. mtDNA damage was quantified by comparing the relative efficiency of amplification of long fragments of DNA and normalizing this to gene copy numbers by the amplification of smaller fragments, which have a statistically negligible likelihood of containing damaged bases. ${ }^{17,24,26,27}$ To calculate normalized amplification, the long QPCR values were divided by the corresponding short QPCR results to account for potential copy number differences between samples (the mtDNA/total DNA value may be different in the 5 -ng template of total DNA in each PCR tube). The copy number results do not indicate damage.

\section{Computational Methods}

AUTODOCK 4.o MGL Tolls package was used for the docking of imidazopyrazine derivatives to the telomerase. ${ }^{28,29}$ This program uses a Lamarkian Genetic Algorithm (LGA) for the docking of ligand interactions. Telomerase (PDB Code: $3 \mathrm{KYL}$ ) and molecule structure within 3D were optimized by UCSF CHIMERA 1.10 .2 before docking procedure. Telomerase - molecule interactions is evaluated using grid-based atomic affiniyt potentials. The end of the reaction time is calculated the final free energy of interaction from the dispersion-repulsion energies, directional hydrogen bonding, dispersion screened electrostatic states and desolvation. Atomic solvation parameters and fragmental volumes were assigned to the protein atoms with the source program AutoDock Vina included in the AutoDock 4.o free program package. In all the docking simulations we used grid maps with 60x60x60 points. A total of 25 runs using LGA were performed in each separate case were the substrates to be docked were free to rotate around their center single bonds.

\section{Statistical Analysis}

Minitab Release 13.0 statistical software was used for analysis. The results were estimated with Mann-Whitney Test. 


\section{RESULTS AND DISCUSSION}

According to the results, 2n code 6-(4-Metylphenyl-8-(4-chlorophenyl) imidazo[1,2-a]pyrazine $\left(\mathrm{C}_{19} \mathrm{H}_{14} \mathrm{~N}_{3} \mathrm{Cl}\right)$ compound inhibited telomerase activities at statistically significant degree (Table 2). Also, 2j, 2m, 20 and $2 \mathrm{p}$ compounds slightly decreased telomerase activity, but this inhibition was not statistically significant. The effect of an Imidazo(1,2-a)pyrazine derivative changes according to side groups (R groups) connected to this molecule. ${ }^{30}$

There are many studies which draw attention to anticancer activities of Imidazo(1,2-a)pyrazine derivatives. In their study which was published in 2012, Leng et al. analyzed structure-activity relation with QSAR method and suggested that some of imidazopyrazine derivatives can function as Aurora A kinase inhibitors ${ }^{31}$ Mitchell and his team stated that imidazo(1,2-a)pyrazine diaryl urea compounds can function as receptor tyrosine kinase inhibitors. This development raised hopes for them in using for the treatment of various diseases including cancer. ${ }^{32}$ When patent studies carried out for these compounds are considered, it can be seen that there are various patents taken as protein kinase inhibitor. In the study of Matthews et al., it is stated that most of the 3,6-di(hetero)diaryl imidazo(1,2-a)pyrazine derivatives are inhibitors of checkpoint kinase 1 (CHK1) and other kinases. ${ }^{33}$ Signal ways which regulate mTOR which is another checkpoint kinase are frequently activated in human cancer. There are patents and essays about use of imidazopyrazine derivates as mTOR inhibitor. ${ }^{34}$ There are also patent records about use of imidazopyrazine derivatives as spleen tyrosine kinase (SYK) (US20100152159 A1 ${ }^{35}$, US20120220582 $\mathrm{A1}^{36}$ ). This enyzme is especially regarded important in B cell lymphoma. B cell receptor (BCR) signals activates SYK and other related ways. BCR and molecules activated by them form important targets for cancer treatment. ${ }^{37}$ Also there are specific information in some resources that imidasol derivatives inhibit topoisomerase II and induce apoptosis..$^{38}$

In their study which was carried out by Prevost et al. in 2006, it was revealed that BIM-46174 which is an imidazopyrazine derivative functions as an inhibitor of $\mathrm{G}$ protein receptor complex in the cell. In this essay it is pointed out $\mathrm{G}$ protein receptors which has an important role in triggering and progressing of cancer can be targeted by imidazopyrazine derivatives. ${ }^{39}$

According to results of our study, some of Imidazo[1,2-a]pyrazine derivatives can be used in order to enable telomerase inhibition. In the application of $2 \mathrm{n}$ code 6-(4-Metylphenyl-8-(4-chlorophenyl)imidazo[1,2-a]pyrazine $\left(\mathrm{C}_{19} \mathrm{H}_{14} \mathrm{~N}_{3} \mathrm{Cl}\right.$ ), it was determined that they inhibit telomerase activities at statistically significant degree (Table 2). 
Table 2. Relative Telomerase activity, mtDNA relative amplification and mtDNA copy number results.

\begin{tabular}{|l|l|l|l|}
\hline Groups & $\begin{array}{l}\text { Relative Telomerase } \\
\text { Activity } \pm \text { SE }\end{array}$ & $\begin{array}{l}\text { mtDNA Relative } \\
\text { Amplification } \pm \text { SE }\end{array}$ & $\begin{array}{l}\text { mtDNA Copy } \\
\text { Number } \pm \text { SE }\end{array}$ \\
\hline Control & $0,428 \pm 0,167^{\star}$ & $2,519 \pm 0,204$ & $101,3 \pm 8,7$ \\
\hline Control $2(\mathrm{DMSO})$ & $2,265 \pm 0,770$ & $1,841 \pm 0,377$ & $112,2 \pm 10,4$ \\
\hline $2 \mathrm{j}\left(10^{-5} \mathrm{M}\right)$ & $1,408 \pm 0,430$ & $2,115 \pm 0,455$ & $107,1 \pm 5,8$ \\
\hline $2 \mathrm{~m}\left(10^{-5} \mathrm{M}\right)$ & $1,825 \pm 0,401$ & $1,735 \pm 0,392$ & $104,2 \pm 7,9$ \\
\hline $2 \mathrm{n}\left(10^{-5} \mathrm{M}\right)$ & $0,551 \pm 0,182^{*}$ & $1,568 \pm 0,173$ & $85,54 \pm 9,2$ \\
\hline $20\left(10^{-5} \mathrm{M}\right)$ & $1,570 \pm 0,260$ & $1,602 \pm 0,301$ & $97,02 \pm 5,6$ \\
\hline $2 \mathrm{p}\left(10^{-5} \mathrm{M}\right)$ & $1,724 \pm 0,383$ & $2,050 \pm 0,409$ & $109,1 \pm 10,1$ \\
\hline
\end{tabular}

"Statistically different from control 2 (DMSO) group ( $<<0,05)$.

The obtained results from computational docking studies also supported the our experimental results. Overall the calculations results are pointed that the compound, 2n, was shown to be more active than the other compounds (Figure 2). Hydrogen bondings and van der waals interactions were made intensely by $2 \mathrm{n}$ especially in some regions of active site of telomerase and these $\mathrm{H}$ bondings have lower binding energy.

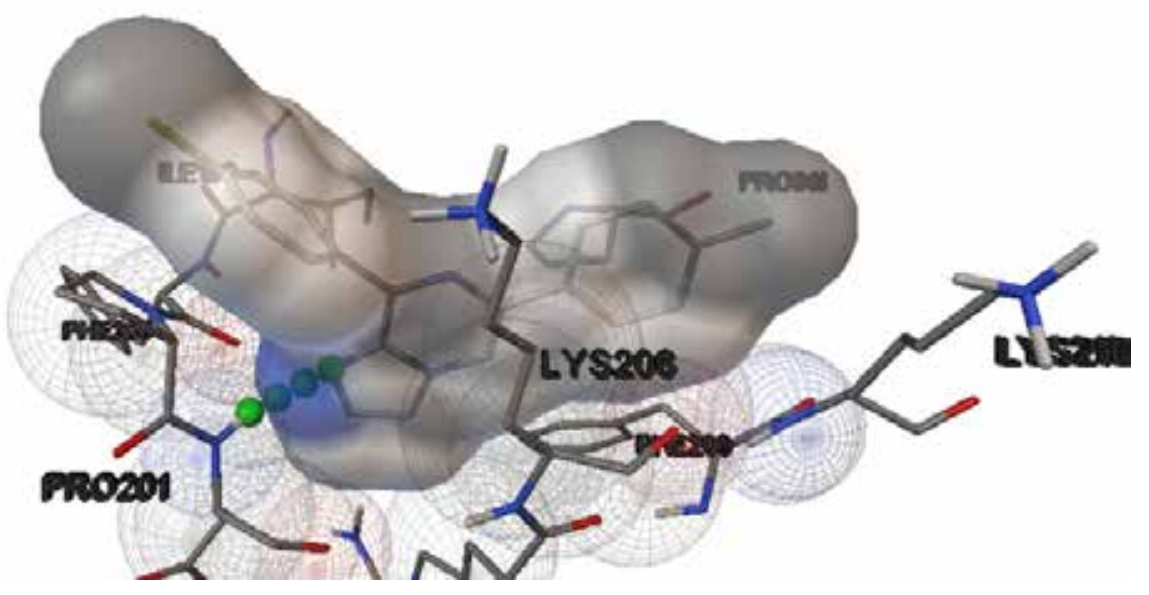

Figure 2. One of the binding positions of 6-(4-Methylphenyl)-8-(4-chlorophenyl) imidazo[1,2-a]pyrazine (2n) with telomerase enzyme (PDB Code: $3 \mathrm{KYL}$ ).

Clinical studies for telomerase inhibition are currently carried out in three different ways as direct telomerase inhibition through drugs such as Imetelstat (GRN163L), as gene therapy and as immunotherapy practices aiming cells which represent telomerase. In recent studies; some of the telomerase inhibitors were tried on bone marrow, prostate, brain, breast cancer and pancreas cancer cells 
and there was decrease in the number of cancer cells. ${ }^{11}$ According to our results, it was found out that the compound, 2n, has the probability to be used as an anticancer agent after detailed studies.

Moreover, in our study it was observed that dimetylsulphoxide (DMSO) which is used for solving chemical substances, increases telomerase activity. In the study of De Mat et al.; it was determined that cell line which is known to have no/low telomerase activity increase telomerase activity as a result of being exposed to DMSO.$^{40}$ In a study which was carried out about differentiation of embrionic stem cell on rats, TERT gene representation raised as a result of dimetylsulphoxide (DMSO) application on each individual and telomerase activity increased. ${ }^{41}$

There were no significant differences among the groups in terms of mtDNA damage or copy number. According to our results, these compounds are not toxic to mtDNA. This is an advantage for the potential usage of the molecules as drugs.

\section{CONCLUSION}

The most important disadvantage of chemotherapy drugs used commonly today is that they are not selective. In this way, they have effect on normal healthy cells together with cancer cells. Telomerase inhibition enables more spesific ground. Cancer cells which can be divided limitlessly due to telomerase activation may lose this characteristics through inhibition of telomerase enzyme. According to our results, 2n code 6-(4-Metylphenyl-8-(4-chlorophenyl)imidazo[1,2-a]pyrazine $\left(\mathrm{C}_{19} \mathrm{H}_{14} \mathrm{~N}_{3} \mathrm{Cl}\right)$ compound inhibit telomerase activities at statistically significant degree. It is evaluated that this compound has the probability to be used as an anti-cancer agent after detailed studies. Moreover, the importance of our study increase by making contribution to the literature since cancer disease has no therapy which is effective for all cancer types, therefore it is an important health problem for all people.

\section{ACKNOWLEDGEMENTS}

This study was supported by the Mehmet Akif Ersoy University Scientific Research Projects Unit (Project numbers: 0305-NAP-16 and 0214-YL-14).

\section{REFERENCES}

1. DeVita, V.T.; Chu, E. A History of Cancer Chemotherapy. Cancer Res. 2oo8, 68, 8643-8653.

2. Mitchell, S.A.; Currie, K.S.; DeSimone, R.W.; Pippin D.A. Certain 8-heteroaryl-6-phenyl-imidazo[1,2-a]pyrazines as modulators of kinase activity. US 7189723 B2. 2007.

3. Goodacre, S.C.; Hallett, D.J.; Street, L.J. Imidazo-pyrazine derivatives as ligands for gaba receptors. WO 2002010170 A1. 2002. 
4. Mitchell, S.A.; DeSimone, R.W.; Darrow, J.W.; Pippin D.A; Danca, M.D. Certain substituted imidazo[1,2-a]pyrazines, as modulators of kinase activity. US 7259164 B2. 2007.

5. Currie, K.S.; DeSimone, R.W.; Mitchell, S.A.; Pippin D.A. Certain heterocyclic substituted imidazo[1,2-A]pyrazin-8-ylamines and methods of inhibition of Bruton's tyrosine kinase by such compounds. US 7393848 B2. 2008.

6. Demirayak, S.; Kayagil, I. Synthesis of Some 6,8-Diarylimidazo[1,2-a]pyrazine Derivatives by Using Either Reflux or Microwave Irradiation Method and Investigation of Their Anticancer Activities. J Heterocyclic Chem. 2005, 42, 319-325.

7. Blackburn, E.H. Switching and signaling at the telomere. Cell. 2001, 106, 661-673.

8. Greider, C.W.; Blackburn, E.H. Identification of a specific telomere terminal transferase activity in Tetrahymena extracts. Cell. 1985, 43, 405-413.

9. Artandi, S.E.; Depinho, R.A. Telomeres and telomerase in cancer. Carcinogenesis. 2010, 31, 9-18.

10. Shay, J.W.; Reddel, R.R.; Wright, W.E. Cancer and telomeres an alternative to telomerase. Science. 2012, 336, 1388-1390.

11. Buseman, C.M.; Wright, W.E.; Shay, J.W. Is telomerase viable target in cancer. Mutat Res. 2012, 730, 90-97.

12. Boccardi, V.; Paolisso, G. Telomerase activation: a potential key modulator for human healthspan and longevity. Ageing Res Rev. 2014, 15, 1-5.

13. Bodnar, A.G.; Ouelette, M.; Frolkis, M.; Holt, S.E.; Chiu, C.; Morin, G.B.; Harley, C.B.; Shay, J.W.; Lichtsteiner, S.; Wright, W.E. Extension of life-span by introduction of telomerase into normal human cells. Science. 1998, 279, 349-352.

14. Harley, C.B.; Futcher, A.B.; Greider, C.W. Telomerase shorten during ageing of human fibroblasts. Nature. 1991, 345, 458-460.

15. De Jesus, B.B.; Vera, E.; Schneeberger, K.; Tejera, A.M.; Ayuso, E.; Bosch, F.; Blasco, M.A. Telomerase gene therapy in adult and old mice delays aging and increases longevity without increasing cancer. EMBO Mol. Med. 2012, 4, 691-704.

16. De Jesus, B.B.; Blasco, M.A. Telomerase at the intersection of cancer and aging. Trends Genet. 2013, 29, 513-520.

17. Mutlu, A.G.; Fiskin, K. Can Vitamin E and Selenium Prevent Cigarette Smoke-Derived Oxidative mtDNA Damage? Turk J Biochem. 2009, 34, 167-172.

18. Mutlu, A.G. Increase in Mitochondrial DNA Copy Number in Response to Ochratoxin A and Methanol-Induced Mitochondrial DNA Damage in Drosophila. Bulletin of Environmental Contamination and Toxicology. 2012, 89, 1129-1132.

19. Mutlu, A.G. The Effects of Potassium Permanganate, Potassium Dichromate and Potassium Perchlorate on Mitochondrial DNA ; Another Possible Mechanism of Dichromate Toxicity . Fresenius Environmental Bulletin. 2014, 23, 920-923.

20. Lesnefsky, E.J.; Moghaddas, S.; Tandler, B.; Kerner, J.; Hoppel, C.L. Mitochondrial dysfunction in cardiac disease: ischemia -reperfusion, aging and heart failure. $J$ Mol Cell Cardiol. 2001, 33, 1065-1089.

21. Liang, F-Q.; Godley, B.F. Oxidative stres induced mtDNA damage in human retinal pigment epithelial cells: a possible mechanism for RPE aging and ge-related macular degeneration. $E x$ perimental Eye Research. 2003, 76, 397-403. 
22. Kishi, S.; Uchiyama, J.; Baughman, A.M.; Goto, T.; Lin, M.C.; Tsai, S.B. The zebrafish as a vertebrate model of functional aging and very gradual senescence. Experimental Gerontology. 2003, $38,777-786$.

23. Henriques, C.M.; Carneiro, M.C.; Tenente, I.M.; Jacinto, A.; Ferreira, M.G. Telomerase Is required for Zebrafish lifespan. PLOS Genet. 2013, 9(1), e1003214.

24. Santos, J.H.; Mandavilli, B.S.; Van Houten, B. Measuring oxidative mtDNA damage and repair using QPCR, In: Copeland, W.C. (eds.), Mitochondrial DNA Methods and Protocols, Humana Pres Inc, Totawa NJ, 2002; pp 159-176.

25. Mutlu, A.G. Measuring of DNA damage by quantitative PCR. In: Hernandez-Rodriguez and Gomez (eds.), Polymerase Chain Reaction, Intech, Rijeka, Crotia, 2012; pp 283-294.

26. Venkatraman, A.; Landar, A.; Davis, A.J.; Chamlee, L.; Sandersoni, T.; Kim, H.; Page, G.; Pompilius, M.; Ballinger, S.; Darley-Usmar, V.; Bailey, S.M. Modification of the mitochondrial proteome in response to the stres of ethanol-dependent hepatoxicity. J Biol Chem. 2004, 279, 22092-22101.

27. Yakes, F.M.; Van Houten, B. Mitochondrial DNA damage is more extensive and persists longer than nuclear DNA damage in human cells following oxidative stres. Proc Natl Acad Sci USA. 1997, 94, 514-519.

28. Jiang, J.; Miracco, E.J.; Hong, K.; Eckert, B.; Chan, H.; Cash, D.D.; Min, B.; Hong Zuhou, Z.; Collins, K.; Feigon, J. The architecture of Tetrahymena telomerase holoenzyme. Nature. 2013 , 496, 187-192.

29. Mitchell, M.; Futahashi, M.; Fujiwara, H.; Skordalakes, E. Structural basis for telomerase catalytic subunit TERT binding to RNA template and telomeric DNA. Nat. Struct. \& Molec. Biology. 2010, 17, 513-518.

30. Myadaraboina, S.; Alla, M.; Saddanapu, V.; Bommena, V.R.; Addlagatta, A. Structure activity relationship studies of imidazo[1,2-a]pyrazine derivatives against cancer cell lines. European Journal of Medicinal Chemistry. 2010, 45, 5208-5216.

31. Leng, Y.; Lu, T.; Yuan, H.L.; Liu, H.C.; Lu, S.; Zhang, W.W.; Jiang, Y.L.; Chen, Y.D. QSAR studies on imidazopyrazine derivatives as Aurora A kinase İnhibitors. SAR and QSAR in Environmental Research. 2012, 23, 705-730.

32. Mitchell, S.A.; Danca, M.D.; Blomgren, P.A.; Darrow, J.W.; Currie, K.S.; Kropf, J.E.; Lee, S.H.; Gallion, S.L.; Xiong, J.M.; Pippin, D.A.; DeSimone, R.W.; Brittelli, D.R.; Eustice, D.C.; Bourret, A.; Hill-Drzewi, M.; Maciejewski, P.M.; Elkin, L.L. Imidazo[1,2-a]pyrazine diaryl ureas: Inhibitors of the receptor tyrosine kinase EphB4. Bioorganic \& Medicinal Chemistry Letters. 2009, 19, 6991-6995.

33. Matthews, T.P.; McHardy, T.; Klair, S.; Boxall, K.; Fisher, M.; Cherry, M.; Allen, C.E.; Addison, G.J.; Ellard, J.; Aherne, G.W.; Westwood, I.M.; Montfort, R.; Garrett, M.D.; Reader, J.C.; Collins, I. Design and evaluation of 3,6-di(hetero)aryl imidazo[1,2-a]pyrazines as inhibitors of checkpoint and other kinases. Bioorganic \& Medicinal Chemistry Letters. 2010, 20, 40454049 .

34. Rosse, G. Imidazopyrazine Derivatives As Inhibitors of mTOR. ACS Med Chem Lett. 2013 , 4, 498-499.

35. Mitchell, S.A.; Currie, K.S.; Blomgren, P.A.; Kropf, J.E.; Lee, S.H.; Xu, J.; Stafford, D.G. Imidazopyrazine syk inhibitors. US 20100152159 A1. 2010. 
36. Mitchell, S.A.; Currie, K.S. Imidazopyrazine syk inhibitors. US 20120220582 A1. 2012.

37. Chen, L.; Monti, S.; Juszczynski, P.; Ouyang. J.; Chapuy, B.; Neuberg, D.; Doench, J.G.; Bogusz, A.M.; Habermann, T.M.; Dogan, A.; Witzig, T.E.; Kutok, J.L.; Rodig, S.J.; Golub, T.; Shipp, M.A. SYK Inhibition Modulates Distinct PI 3 K/AKTDependent Survival Pathways and Cholesterol Biosynthesis in Diffuse Large B Cell Lymphomas. Cancer Cell. 2013, 23, 826-838.

38. Baviskar, A.T.; Madaan, C.; Preet, R.; Mohapatra, P.; Jain, V.; Agarwal, A.; Guchhait, S.K.; Kundu, C.N.; Banerjee, U.C.; Bharatam, P.V. N-fused imidazoles as novel anticancer agents that inhibit catalytic activity of topoisomerase II $\alpha$ and induce apoptosis in $\mathrm{G} 1 / \mathrm{S}$ phase. $J$ Med Chem. 2011, 54, 5013-30.

39. Prevost, G.P.; Lonchampt, M.O.; Holbeck, S.; Attoub, S.; Zaharevitz, D.; Alley, M.; Wright, J.; Brezak, M.C.; Coulomb, H.; Savola, A.; Huchet, M.; Chaumeron, S.; Nguyen, Q.D. et al. Anticancer activity of BIM-46174, a new inhibitor of the heterotrimeric $\mathrm{G}$ alpha/G beta gamma protein complex. Cancer Res. 2006, 66, 9227-9234.

40. Alfonso-De Matte, A.M.Y.; Cheng, J.Q.; Kruk, P.A. Ultraviolet Irradiation- and Dimethyl Sulfoxide-Induced Telomerase Activity in Ovarian Epithelial Cell Lines. Experimental Cell Research. 2001, 267, 13-27.

41. Armstrong, L.; Lako, M.; Lincoln, J.; Cairns, M.P.; Hole, N. mTERT expression correlates with telomerase activity during the differentiation of murine embryonic stem cells. Mechanisms of Development. 2000, 97, 109-116.

(Received 22 March 2017; Accepted 24 April 2017) 